\title{
Shifts in dimethylated sulfur concentrations and microbiome composition in the red-tide causing dinoflagellate Alexandrium minutum during a simulated marine heatwave
}

\author{
Elisabeth Deschaseaux ${ }^{1}$, James O'Brien ${ }^{1}$, Nachshon Siboni ${ }^{1}$, Katherina Petrou ${ }^{1,2}$, and Justin R. Seymour ${ }^{1}$ \\ ${ }^{1}$ University of Technology Sydney, Climate Change Cluster, Ultimo NSW 2007, Australia \\ ${ }^{2}$ University of Technology Sydney, School of Life Sciences, Ultimo NSW 2007, Australia
}

Correspondence: Elisabeth Deschaseaux (elisabeth.deschaseaux@gmail.com)

Received: 4 December 2018 - Discussion started: 17 December 2018

Revised: 10 September 2019 - Accepted: 18 September 2019 - Published: 19 November 2019

\begin{abstract}
The biogenic sulfur compounds dimethyl sulfide (DMS), dimethyl sulfoniopropionate (DMSP) and dimethyl sulfoxide (DMSO) are produced and transformed by diverse populations of marine microorganisms and have substantial physiological, ecological and biogeochemical importance spanning organism to global scales. Understanding the production and transformation dynamics of these compounds under shifting environmental conditions is important for predicting their roles in a changing ocean. Here, we report the physiological and biochemical response of a robust strain of Alexandrium minutum, a dinoflagellate with the highest reported intracellular DMSP content, exposed to a $6 \mathrm{~d}$ increase in temperature mimicking mild and extreme coastal marine heatwave conditions $\left(+4\right.$ and $\left.+12^{\circ} \mathrm{C}\right)$. Under mild temperature increases $\left(+4^{\circ} \mathrm{C}\right), A$. minutum growth was enhanced, with no measurable physiological stress response. However, under a very acute increase in temperature $\left(+12^{\circ} \mathrm{C}\right)$ triggering thermal stress, A. minutum growth declined, photosynthetic efficiency $\left(F_{\mathrm{V}} / F_{\mathrm{M}}\right)$ was impaired, and enhanced oxidative stress was observed. These physiological responses indicative of thermal stress were accompanied by increased DMS and DMSO concentrations followed by decreased DMSP concentration. At this temperature extreme, we observed a cascading stress response in A. minutum, which was initiated $6 \mathrm{~h}$ after the start of the experiment by a spike in DMS and DMSO concentrations and a rapid decrease in $F_{\mathrm{V}} / F_{\mathrm{M}}$. This was followed by an increase in reactive oxygen species (ROS) and an abrupt decline in DMS and DMSO on day 2 of the experiment. A subsequent decrease in DMSP coupled with a decline in the growth rate of both A. minutum and its associated total bacterial assemblage
\end{abstract}

coincided with a shift in the composition of the A. minutum microbiome. Specifically, an increase in the relative abundance of the operational taxonomic units (OTUs) matching Oceanicaulis (17.0\%), Phycisphaeraceae SM1A02 $(8.8 \%)$ and Balneola (4.9\%) as well as a decreased relative abundance of Maribacter (24.4\%), Marinoscillum (4.7\%) and Seohaeicola $(2.7 \%)$ were primarily responsible for differences in microbiome structure observed between temperature treatments. These shifts in microbiome structure are likely to have been driven by either the temperature itself, the changing physiological state of $A$. minutum cells, shifts in biogenic sulfur concentrations, the presence of other solutes, or a combination of all. Nevertheless, we suggest that these results point to the significant effect of extreme heatwaves on the physiology, growth and microbiome composition of the redtide causing dinoflagellate $A$. minutum, as well as potential implications for biogenic sulfur cycling processes and marine DMS emissions.

\section{Introduction}

Many marine phytoplankton produce the organic sulfur compound dimethyl sulfoniopropionate (DMSP) (Zhou et al., 2009; Berdalet et al., 2011; Caruana and Malin, 2014), as it can function as an antioxidant, osmolyte, chemoattractant and currency in reciprocal chemical exchanges with heterotrophic bacteria (Stefels, 2000; Sunda et al., 2002; Kiene et al., 2000; Seymour et al., 2010). Phytoplankton-derived DMSP is in fact a major source of sulfur and carbon for marine heterotrophic bacteria (Kiene et al., 2000), which in turn 
play a major role in the cycling and turnover of organosulfur compounds in the ocean (Todd et al., 2007; Curson et al., 2011). The subsequent cycling of DMSP into other biogenic sulfur molecules including dimethyl sulfide (DMS) and dimethyl sulfoxide (DMSO) by a suite of microbial transformation pathways (Kiene et al., 2000; Sunda et al., 2002) and physical drivers (Brimblecombe and Shooter, 1986) have important ecological and biogeochemical implications spanning from cellular to global scales (Sunda et al., 2002; Charlson et al., 1987; DeBose et al., 2008; Van Alstyne et al., 2001; Knight, 2012; Nevitt et al., 1995).

Among DMSP-producing phytoplankton, the dinoflagellate Alexandrium minutum has the highest recorded DMSP cell content, with an average concentration of 14.2 pmol cell $^{-1}$, compared with less than 1 pmolcell ${ }^{-1}$ in most other dinoflagellates (Caruana and Malin, 2014). Blooms of A. minutum occur from the Mediterranean Sea to the South Pacific coast in sea surface waters within temperature ranges of 12 to $25^{\circ} \mathrm{C}$ (Laabir et al., 2011). Notably, some strains of Alexandrium, including A. minutum, produce saxitoxins, which lead to paralytic shellfish poisoning (PSP) and are responsible for the most harmful algal blooms in terms of magnitude, distribution and consequences on human health (Anderson et al., 2012).

A. minutum commonly inhabits shallow coastal and estuarine waters (Anderson, 1998), which are globally experiencing substantial shifts in environmental conditions, including increases in sea surface temperature (SST) associated with climate change (Harley et al., 2006). Although generally less studied than chronic temperature rises associated with global climate change (Frölicher and Laufkötter, 2018), acute ephemeral temperature increases known as marine heatwaves (MHWs) (Hobday et al., 2016) have recently been demonstrated to be becoming more frequent and persistent as a consequence of climate change (Oliver et al., 2018). Increases in MHW occurrence are anticipated to become particularly frequent within the shallow coastal and estuarine waters, where A. minutum blooms occur (Ummenhofer and Meehl, 2017; Anderson, 1998).

Coastal MHW events have recently had dramatic impacts on coastal environments. MHWs of up to $6{ }^{\circ} \mathrm{C}$ increase in temperature in Western Australian coastal waters (2011) and the northeast Pacific (2013-2015) resulted in significant ecosystem shifts with increases in novel species at the expenses of others (Frölicher and Laufkötter, 2018). The 2016 MHW that was associated with El Niño-Southern Oscillations resulted in an $8^{\circ} \mathrm{C}$ increase in sea surface temperature leading to the mass coral bleaching of more than $90 \%$ of the Great Barrier Reef (Hughes et al., 2017). While it is clear that MHWs can have severe consequences on a variety of systems and organisms, their effects on marine microbes and the biogeochemical processes that they mediate have rarely been investigated (Joint and Smale, 2017).

While there is evidence that increases in seawater temperature can lead to increased DMSP and/or DMS concentrations in phytoplankton (McLenon and DiTullio, 2012; Sunda et al., 2002), it is not clear how a shift in DMSP net production by phytoplankton under acute temperature stress will alter the composition and function of their associated microbiome and how, in turn, this will influence biogenic sulfur cycling processes within marine habitats. There is therefore a pressing need to understand the physiological and biogeochemical consequences of thermal stress on phytoplankton-bacteria interactions within the context of events such as MHWs. This is particularly important, given that a shift in the composition of the phytoplankton microbiome could potentially dictate atmospheric DMS fluxes depending on whether the bacterial community preferentially cleaves or demethylates DMSP (Todd et al., 2007; Kiene et al., 2000).

The aims of this study were to investigate how an acute increase in temperature $\left(+12^{\circ} \mathrm{C}\right)$, comparable to those associated with MHW events and leading to thermal stress in A. minutum could alter the physiological state and biogenic sulfur cycling dynamics of $A$. minutum and determine how these changes might influence the composition of the Alexandrium microbiome. We hypothesised that an abrupt increase in temperature would lead to physiological impairment (Falk et al., 1996; Robison and Warner, 2006; Iglesias-Prieto et al., 1992; Rajadurai et al., 2005) and oxidative stress (Lesser, 2006) in A. minutum, leading to an upregulation of DMSP, DMS and DMSO production (McLenon and DiTullio, 2012; Sunda et al., 2002) in this high DMSP producer, which could ultimately lead to a shift in the composition of the A. minutum microbiome.

\section{Methods}

\subsection{Culturing and experimental design}

Cultures of Alexandrium minutum (CS-324), isolated from southern Australian coastal waters (Port River, Adelaide, 11 November 1988, CSIRO, ANACC's collection) were grown in GSe medium at $18^{\circ} \mathrm{C}$ and $50 \mu$ mol photons $\mathrm{m}^{-2} \mathrm{~s}^{-1}$ under a $12: 12$ light : dark cycle. One month before the start of each experiment, A. minutum cultures were acclimated over four generations to $20^{\circ} \mathrm{C}$ (average summer temperature at Port River, IMOS) and $200 \mu \mathrm{mol} \mathrm{photons} \mathrm{m}^{-2} \mathrm{~s}^{-1}$ using a $14: 10 \mathrm{~h}$ light: dark cycle mimicking summer conditions. Light intensity was comparable to that used in Berdalet et al. (2011) for A. minutum and conveniently allowed the growth of other algae cultures using the same facilities. Cultures were grown to a cell concentration of $\sim 60000 \mathrm{~mL}^{-1}$ before cells were inoculated into fresh GSe medium. $6 \mathrm{~d}$ prior to the start of each experiment, $20 \mathrm{~L}$ of GSe medium was inoculated with a cell concentration of $1140 \mathrm{~mL}^{-1}$ (experiment 1, April 2016) and $680 \mathrm{~mL}^{-1}$ (experiment 2, June 2016) and aliquots of $500 \mathrm{~mL}$ were transferred into 40 individual $750 \mathrm{~mL}$ sterile tissue culture flasks. Culture flasks were incubated in four independent water 
baths (10 flasks in each) and maintained under control conditions of $20^{\circ} \mathrm{C}$ and $200 \mu \mathrm{mol}$ photons $\mathrm{m}^{-2} \mathrm{~s}^{-1}$. Temperature and light control was achieved using circulating water heaters (Julabo USA, Inc.) and programmable LED lights (Hydra FiftyTwo, Aqualllumination, USA). All cultures were mixed twice daily to keep cells in suspension by gentle swirling.

On day $1\left(T_{0}\right)$, five culture flasks from each $20^{\circ} \mathrm{C}$ water bath were transferred to four new water baths for exposure to experimental treatment temperatures (either $24^{\circ} \mathrm{C}$ in experiment 1 or $32^{\circ} \mathrm{C}$ in experiment 2) so that each control and experimental water bath contained five flasks. Experimental temperatures were carefully chosen based on preliminary experiments conducted at $24,28,30$ and $32^{\circ} \mathrm{C}$, where only a $12{ }^{\circ} \mathrm{C}$ increase in temperature $\left(32^{\circ} \mathrm{C}\right.$ treatment $)$ led to a physiological stress response in this robust strain of A. minutum in culture. Although an increase in temperature of this magnitude might be rare in coastal marine systems, this presented a unique opportunity to investigate the consequences of MHW-induced thermal stress on this relevant phytoplankton. One culture flask from each tank was immediately sampled for baseline measurements of the following: DMS (2 mL), DMSP and DMSO $(1 \mathrm{~mL})$ concentrations, photochemical efficiency $(3 \mathrm{~mL})$, algal and bacterial cell counts $(1 \mathrm{~mL})$, ROS quantification $(1 \mathrm{~mL})$ and DNA extraction $(\sim 470 \mathrm{~mL})$. The dissolved DMSP fraction was not determined because preliminary investigations showed that gravity filtration was too time consuming, potentially due to clogging of filters by the large A. minutum cells ( $30 \mu \mathrm{m}$ diameter), leading to filtration artefacts for DMSP analysis, as previously mentioned by Berdalet et al. (2011). At 18:00 AEDT on day $1\left(T_{6}\right), 12: 00$ on day $2\left(T_{24}\right), 12: 00$ on day $5\left(T_{96}\right)$ and 12:00 on day $6\left(T_{120}\right)$ one flask from each of the eight water baths was removed from the incubation conditions and sampled as described above.

\subsection{Photosynthetic efficiency measurements}

Subsamples for measurement of photosynthetic efficiency were dark adapted for 10 min under aluminium foil and transferred to a quartz cuvette for pulse amplitude modulated (PAM) fluorometric analysis using a WATER PAM (Walz $\mathrm{GmbH}$, Effeltrich, Germany). Once the base fluorescence $\left(F_{0}\right)$ signal had stabilised (measuring light intensity 3, frequency $2 \mathrm{~s}$ ), a saturating pulse (intensity 12 , width $0.8 \mathrm{~s}$ ) was used to measure the maximum quantum yield $\left(F_{\mathrm{V}} / F_{\mathrm{M}}\right)$ of photosystem II (PSII). As base fluorescence is dependent on cell density, the photomultiplier gain was adjusted and recorded to maintain $F_{0}$ at a level of 0.2 a.u. before saturating the photosystem. Samples were kept in suspension during measurements via continuous stirring at minimal speed inside the quartz cuvette to avoid cells settling.

\subsection{Microalgal and bacterial cell counts}

Subsamples for bacterial cell counts were stained with SYBR Green at a final concentration of $1: 10000$ and incubated in the dark for $15 \mathrm{~min}$ (Marie et al., 1997). Subsamples for microalgal cell counts and stained subsamples for bacterial cell counts were diluted $1: 10$ and $1: 100$ respectively into sterile GSe medium prior to analysis with a BD Accuri C6 Flow Cytometer (Becton Dickinson). Phytoplankton cells were discriminated using red autofluorescence and side scatter (SSC), whereas bacterial populations were discriminated and quantified using SYBR Green fluorescence and SSC.

\subsection{Reactive oxygen species measurements}

The presence of reactive oxygen species (ROS) was detected within cultures using the fluorescent probe 2,7-dichlorodihydrofluorescein-diacetate (CM-H2DCFDA; Molecular Probes), which binds to ROS and other peroxides (Rastogi et al., 2010). The reagent was thawed at room temperature for $10 \mathrm{~min}$ and activated using $86.5 \mu \mathrm{L}$ of DMSO, with $5 \mu \mathrm{L}$ of activated reagent added to each sample (final concentration $5 \mu \mathrm{M})$. Samples were vortexed for $5 \mathrm{~s}$ and incubated at room temperature for $30 \mathrm{~min}$. Samples were then centrifuged at $2000 \mathrm{~g}$ for $2 \mathrm{~min}$, the supernatant with reagent dye was discarded, and stained cells were resuspended in $1 \mathrm{~mL}$ of phosphate-buffered saline (PBS), prior to quantification of fluorescence by flow cytometry. Mean green fluorescence was quantified from cytograms of forward light scatter (FSC) against green fluorescence. A positive control (+10 $\mu \mathrm{L}$ of $30 \% \mathrm{H}_{2} \mathrm{O}_{2}$, final concentration $97 \mathrm{mM}$ ) and negative (no ROS added) control of PBS were run to ensure that detected cell fluorescence was completely attributable to the ROS probe.

\subsection{Sulfur analysis by gas chromatography}

The preparation of all blanks and samples used in the dilution steps described below were prepared with sterile $(0.2 \mu \mathrm{M}$ filtered and autoclaved) phosphate-buffered saline (PBS, salinity $35 \mathrm{ppt}$ ) to avoid cell damage from altered osmolarity and to maintain similar physical properties as seawater during headspace analysis by gas chromatography. Aliquots for DMS analysis were transferred into $14 \mathrm{~mL}$ headspace vials that were immediately capped and crimped using butyl rubber septa (Sigma Aldrich Pty; 27232) and aluminium caps (Sigma Aldrich Pty; 27227-U) respectively. DMSP aliquots were $1: 1$ diluted with sterile PBS, and DMSP was cleaved to DMS by adding 1 pellet of $\mathrm{NaOH}$ to each vial, which was immediately capped and crimped. Samples were incubated for a minimum of $30 \mathrm{~min}$ at room temperature to allow for the alkaline reaction and equilibration to occur prior to analysis by gas chromatography (Kiene and Slezak, 2006).

DMS and DMSP samples were analysed by $500 \mu \mathrm{L}$ direct headspace injections using a Shimadzu gas chromatograph 
(GC-2010 Plus) coupled with a flame photometric detector (FPD) set at $180^{\circ} \mathrm{C}$ with instrument grade air and hydrogen flow rates set at 60 and $40 \mathrm{~mL} \mathrm{~min}^{-1}$, respectively. DMS was eluted on a capillary column $(30 \mathrm{~m} \times 0.32 \mathrm{~mm} \times 5 \mu \mathrm{m})$ set at $120^{\circ} \mathrm{C}$ using high purity helium $(\mathrm{He})$ as the carrier gas at a constant flow rate of $5 \mathrm{~mL} \mathrm{~min}^{-1}$ and a split ratio of 5. A six-point calibration curve and PBS blanks were run by $500 \mu \mathrm{L}$ direct headspace injections prior to subsampling culture flasks using small volumes of concentrated DMSP. $\mathrm{HCl}$ standard solutions (certified reference material WR002, purity $90.3 \pm 1.8 \%$ mass fraction, National Measurement Institute, Sydney, Australia) were diluted in sterile PBS to a final volume of $2 \mathrm{~mL}$. Detection limit was $50 \mathrm{nM}$ for $500 \mu \mathrm{L}$ headspace injections. Concentrations obtained in vials treated with $\mathrm{NaOH}$ accounted for both DMS and DMSP. Consequently, the DMSP concentration in each sample was obtained by subtracting the corresponding DMS concentration.

Following DMS and DMSP analysis, alkaline samples used for DMSP analysis were uncapped and left to vent overnight under a fume hood. On the next day, samples were purged for $10 \mathrm{~min}$ with high purity $\mathrm{N}_{2}$ at an approximate flow rate of $60 \mathrm{~mL} \mathrm{~min}^{-1}$ to remove any remaining DMS produced from the alkaline treatment. Samples were then neutralised by adding $80 \mu \mathrm{L}$ of $32 \% \mathrm{HCl}$, and DMSO was converted to DMS by adding $350 \mu \mathrm{L}$ of $12 \% \mathrm{TiCl}_{3}$ solution to each vial, which were then immediately capped and crimped (Kiene and Gerard, 1994; Deschaseaux et al., 2014b). Vials were then heated in a water bath at $50^{\circ} \mathrm{C}$ for $1 \mathrm{~h}$ and cooled down to room temperature prior to analysis by $500 \mu \mathrm{L}$ direct headspace injections on the GC-FPD as described above. A five-point calibration curve was run prior to DMSO analysis using DMSO standard solutions (Sigma Aldrich Pty; D2650) diluted in PBS to a final volume of $2 \mathrm{~mL}$ and converted to DMS with $\mathrm{TiCl}_{3}$ in the same manner as the experimental samples. PBS blanks treated with $\mathrm{NaOH}$ and $\mathrm{TiCl}_{3}$ were also run along with the calibration curves. All dimethylated sulfur compounds were normalised to cell density, which best reflects biogenic production.

\subsection{DNA extraction}

Following sub-sampling for the physiological and biogenic sulfur measurements described above, the remaining $400 \mathrm{~mL}$ within each culture flask was filtered onto a $47 \mathrm{~mm}$ diameter, $0.22 \mu \mathrm{m}$ polycarbonate filter (Millipore) with a peristaltic pump at a rate of $80 \mathrm{rpm}$ to retain cells for DNA analysis. The filters were subsequently stored in cryovials, snap frozen with liquid nitrogen and stored at $-80^{\circ} \mathrm{C}$ until extraction. DNA extraction was performed using a bead-beating and chemical lysis based DNA extraction kit (PowerWater DNA Isolation Kit, MoBio Laboratories) following the manufacturer's instructions. DNA quantity and purity were checked for each sample using a Nanodrop 2000 (Thermo Fisher Scientific, Wilmington, DE, USA). Three replicate samples with the highest DNA quantity and purity from the control and treatment tanks, collected at the beginning $\left(T_{0}\right)$ and end $\left(T_{120}\right)$ of the experiment, were subsequently sequenced.

\subsection{S rRNA amplicon sequencing and bioinformatics}

To characterise the bacterial assemblage structure (microbiome) of A. minutum cultures, we employed $16 \mathrm{~S}$ rRNA amplicon sequencing. We amplified the V1-V3 variable regions of the $16 \mathrm{~S}$ rRNA gene using the 27F (AGAGTTTGATCMTGGCTCAG, Lane, 1991) and 519R (GWATTACCGCGGCKGCTG, Turner et al., 1999) primer pairing, with amplicons subsequently sequenced using the Illumina MiSeq platform (Ramaciotti Centre for Genomics; Sydney, NSW, Australia) following the manufacturer's guidelines. Raw data files in FASTQ format were deposited in the National Center for Biotechnology Information (NCBI) Sequence Read Archive (SRA) under the study accession number PRJNA486692.

Bacterial 16S rRNA gene sequencing reads were analysed using the QIIME pipeline (Caporaso et al., 2010; Kuczynski et al., 2012). Briefly, paired-end DNA sequences were joined, de novo operational taxonomic units (OTUs) were defined at $97 \%$ sequence identity using UCLUST (Edgar, 2010) and taxonomy was assigned against the SILVA v128 database (Quast et al., 2012; Yilmaz et al., 2013). Chimeric sequences were detected using usearch61 (Edgar, 2010) and together with chloroplast OTUs were filtered from the dataset. Sequences were then aligned, filtered and rarefied to the same depth to remove the effect of sampling effort upon analysis.

\subsection{Statistical analysis}

Repeated measures analysis of variance (rmANOVA) models were fitted to the data to quantify the effects of temperature and time (fixed factors) on all response variables measured in this experiment (cell density, $F_{\mathrm{V}} / F_{\mathrm{M}}$, ROS, DMS, DMSP and DMSO concentrations) using IBM SPSS Statistics 20. Assumptions of sphericity were tested using Mauchly's test. In cases where this assumption was violated, the degrees of freedom were adjusted using the Greenhouse-Geisser correction factor. Bonferroni adjustments were used for pairwise comparisons. Each variable was tested for the assumption of normality and $\log$, ln or square root transformations were applied when necessary.

For sequencing data, alpha diversity parameters of the rarefied sequences and jackknife comparison of the weighted sequence data (beta diversity) were calculated in QIIME (Caporaso et al., 2010). A two-way PERMANOVA with BrayCurtis similarity measurements was performed on abundance data of taxonomic groups that contained more than $1 \%$ of total generated OTUs (represent $90.23 \%$ of the data) using PAST (Hammer et al., 2008). In addition, PAST was used to perform non-metric multidimensional scaling (nMDS) analysis and to isolate the environmental parameters (normalised 
Table 1. Output of repeated measures analysis of variance (rmANOVA) for algal $\left(\right.$ CELLS $\left._{\mathrm{A}}\right)$ and bacterial $\left(\right.$ CELLS $\left._{\mathrm{B}}\right)$ cell abundance, photosynthetic efficiency $\left(F_{\mathrm{V}} / F_{\mathrm{M}}\right)$, oxidative stress (ROS), dimethyl sulfoniopropionate (DMSP), dimethyl sulfide (DMS) and dimethyl sulfoxide (DMSO) concentrations as a function of temperature $\left(24\right.$ or $\left.32^{\circ} \mathrm{C}\right)$ and time. Numbers in bold indicate significant data based on the level of significance $p<0.05$. df1 indicates the numerator $\mathrm{df}$, and $\mathrm{df} 2$ indicates the denominator $\mathrm{df}$.

\begin{tabular}{|c|c|c|c|c|c|c|c|}
\hline \multirow[b]{2}{*}{ Parameters } & & \multicolumn{3}{|c|}{$24{ }^{\circ} \mathrm{C}-$ mild thermal stress } & \multicolumn{3}{|c|}{$32^{\circ} \mathrm{C}-$ acute thermal stress } \\
\hline & & Temperature & Time & Temperature $\times$ time & Temperature & Time & Temperature $\times$ time \\
\hline \multirow{4}{*}{ CELLS $_{\mathrm{A}}$} & $F$ & 4.04 & 335 & 4.16 & 27.47 & 237.62 & 8.28 \\
\hline & df1 & 1 & 4 & 4 & 1 & 2.04 & 2.04 \\
\hline & $\mathrm{df} 2$ & 6 & 24 & 24 & 6 & 12.26 & 12.26 \\
\hline & $p$ & 0.91 & $<0.001$ & 0.01 & $<0.001$ & $<0.001$ & 0.005 \\
\hline \multirow{4}{*}{ CELLS $_{\mathrm{B}}$} & $F$ & 2.13 & 52.2 & 1.35 & 32.56 & 199.8 & 22.26 \\
\hline & df1 & 1 & 1.29 & 1.29 & 1 & 4 & 4 \\
\hline & $\mathrm{df} 2$ & 6 & 7.74 & 7.74 & 6 & 24 & 24 \\
\hline & $p$ & 0.2 & $<0.001$ & 0.3 & 0.001 & $<0.001$ & $<0.001$ \\
\hline \multirow{4}{*}{$F_{\mathrm{V}} / F_{\mathrm{M}}$} & $F$ & 0.42 & 33.43 & 6.9 & 48.79 & 12.58 & 13.11 \\
\hline & df1 & 1 & 4 & 4 & 1 & 1.19 & 1.19 \\
\hline & $\mathrm{df} 2$ & 6 & 24 & 24 & 5 & 5.93 & 5.93 \\
\hline & $p$ & 0.54 & $<0.001$ & 0.001 & 0.001 & 0.01 & 0.01 \\
\hline \multirow{4}{*}{ ROS } & $F$ & 37.26 & 6.3 & 5.88 & 33.23 & 8.85 & 8.41 \\
\hline & df1 & 1 & 4 & 4 & 1 & 2.32 & 2.32 \\
\hline & $\mathrm{df} 2$ & 6 & 24 & 24 & 6 & 13.9 & 13.9 \\
\hline & $p$ & 0.001 & 0.001 & 0.002 & 0.001 & 0.003 & 0.003 \\
\hline \multirow{4}{*}{ DMSP } & $F$ & 0.79 & 31.16 & 0.95 & 3.03 & 15.18 & 3.17 \\
\hline & df1 & 1 & 1.56 & 1.56 & 1 & 4 & 4 \\
\hline & $\mathrm{df} 2$ & 6 & 9.35 & 9.35 & 6 & 24 & 24 \\
\hline & $p$ & 0.41 & $<0.001$ & 0.4 & 0.13 & $<0.001$ & $\mathbf{0 . 0 3}$ \\
\hline \multirow{4}{*}{ DMS } & $F$ & 51.5 & 38.73 & 2.01 & 5.08 & 30.77 & 5.23 \\
\hline & df1 & 1 & 2.14 & 2.14 & 1 & 4 & 4 \\
\hline & $\mathrm{df} 2$ & 6 & 12.87 & 12.87 & 6 & 24 & 24 \\
\hline & $p$ & $<0.001$ & $<0.001$ & 0.17 & 0.07 & $<0.001$ & 0.004 \\
\hline \multirow{4}{*}{ DMSO } & $F$ & 36.56 & 26.64 & 7.21 & 4.68 & 14.74 & 7.14 \\
\hline & df1 & 1 & 4 & 4 & 1 & 4 & 4 \\
\hline & df2 & 6 & 24 & 24 & 6 & 24 & 24 \\
\hline & $p$ & 0.001 & $<0.001$ & 0.001 & 0.07 & $<0.001$ & 0.001 \\
\hline
\end{tabular}

as follows: ( $x$ mean)/SD) that contributed the most to the differences between groups using the Bray-Curtis similarity measure. SIMPER analysis performed with the White $t$ test was used to identify the taxonomic groups that significantly contributed the most to the shift in bacterial composition in A. minutum cultures over time and between temperature treatments.

\section{Results}

\subsection{Algal growth and physiological response}

A. minutum cell abundance exponentially increased over time in both the control $\left(20^{\circ} \mathrm{C}\right)$ and $24^{\circ} \mathrm{C}$ temperature treatment, but a significantly faster growth rate $(p=0.001, t$ test $)$ occurred at $24{ }^{\circ} \mathrm{C}\left(2.66 \pm 0.01 \mathrm{~d}^{-1}\right.$; average $\left.\pm \mathrm{SE}\right)$ compared to the $20^{\circ} \mathrm{C}$ control $\left(2.57 \pm 0.01 \mathrm{~d}^{-1}\right)$, resulting in significantly greater cell abundance at $96 \mathrm{~h}(p=0.007)$ and $120 \mathrm{~h}$ $(p<0.001)$ (rmANOVA, Table 1, Fig. 1a). On the other hand, the $32{ }^{\circ} \mathrm{C}$ treatment resulted in decreased growth rates $\left(2.40 \pm 0.02 \mathrm{~d}^{-1}\right.$ versus $2.58 \pm 0.02 \mathrm{~d}^{-1} ; t$ test $)$ and significantly lower cell abundance, relative to the $20^{\circ} \mathrm{C}$ control, at all time points from $6 \mathrm{~h}$ after the start of the experiment ( $p \leq 0.03$; rmANOVA, Table 1, Fig. 1b). A. minutum abundance demonstrated a marked decline on day 5 in the $32^{\circ} \mathrm{C}$ treatment.

No significant difference in the maximum quantum yield $\left(F_{\mathrm{V}} / F_{\mathrm{M}}\right)$ of $A$. minutum cultures occurred between 20 and $24^{\circ} \mathrm{C}$ until $120 \mathrm{~h}$ after the start of the experiment, where a significantly lower $F_{\mathrm{V}} / F_{\mathrm{M}}$ occurred in the $24{ }^{\circ} \mathrm{C}$ treatment ( $p=0.01$; rmANOVA, Table 1 , Fig. $2 \mathrm{a})$. In contrast, $F_{\mathrm{V}} / F_{\mathrm{M}}$ was significantly lower in $A$. minutum cultures maintained at 


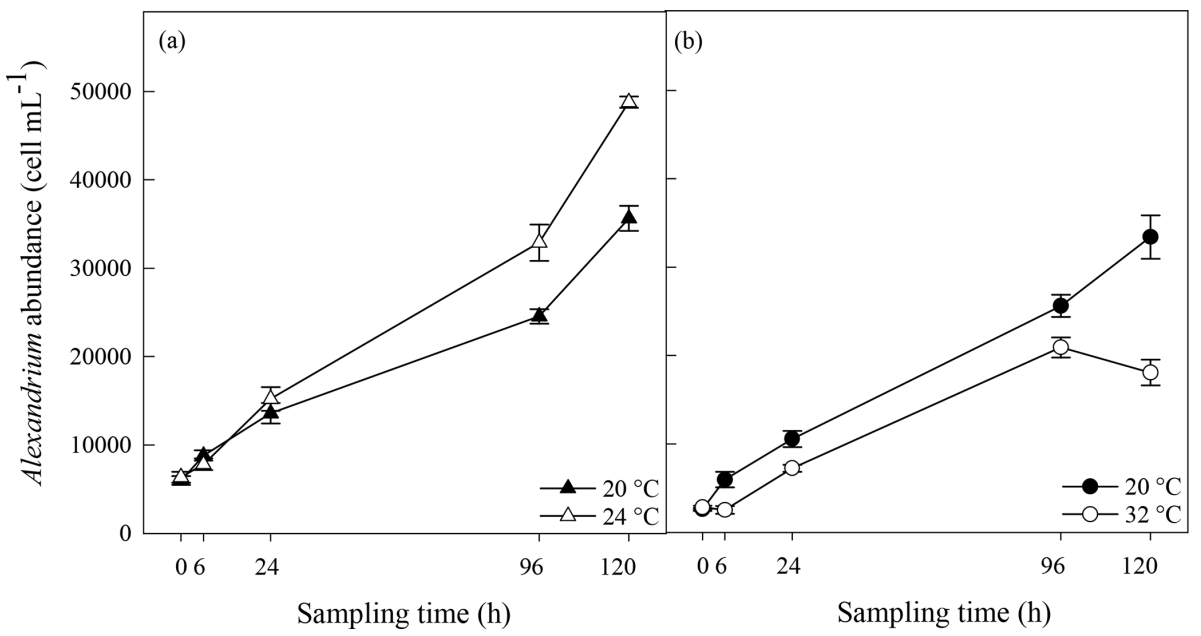

Figure 1. Algal cell abundance in A. minutum cultures in experiment $1\left(20\right.$ and $\left.24^{\circ} \mathrm{C}\right)(\mathbf{a})$ and experiment $2\left(20^{\circ} \mathrm{C}\right.$ and $\left.32^{\circ} \mathrm{C}\right)(\mathbf{b})$; average $\pm \mathrm{SE}, n=4$.

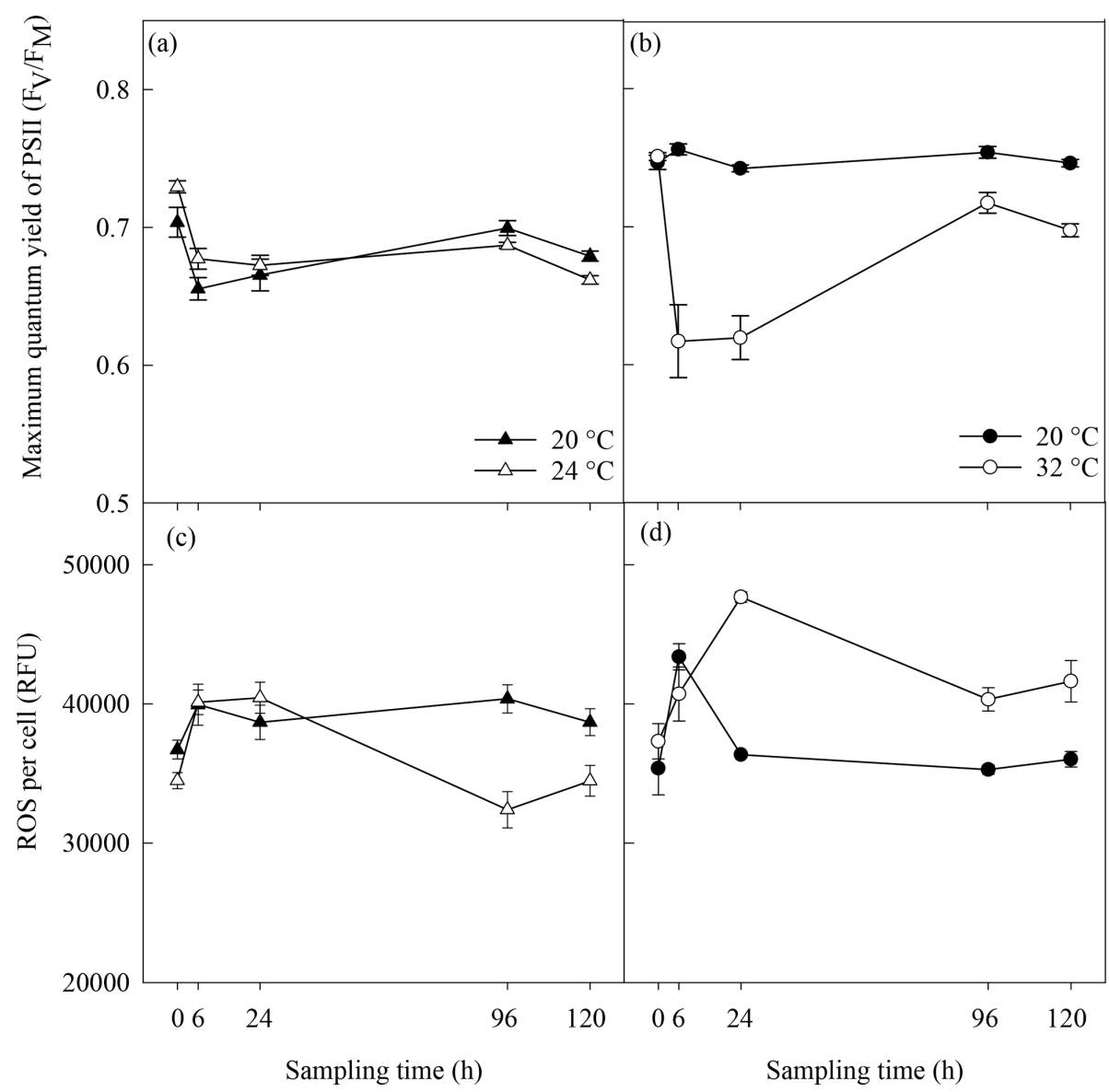

Figure 2. Photosynthetic efficiency (a, b) and reactive oxygen species (ROS) (c, d) in A. minutum cultures in experiment $1\left(20\right.$ and $\left.24^{\circ} \mathrm{C}\right)(\mathbf{a}$, c) and experiment $2\left(20\right.$ and $\left.32^{\circ} \mathrm{C}\right)(\mathbf{b}, \mathbf{d})$; average $\pm \mathrm{SE}, n=4$. 


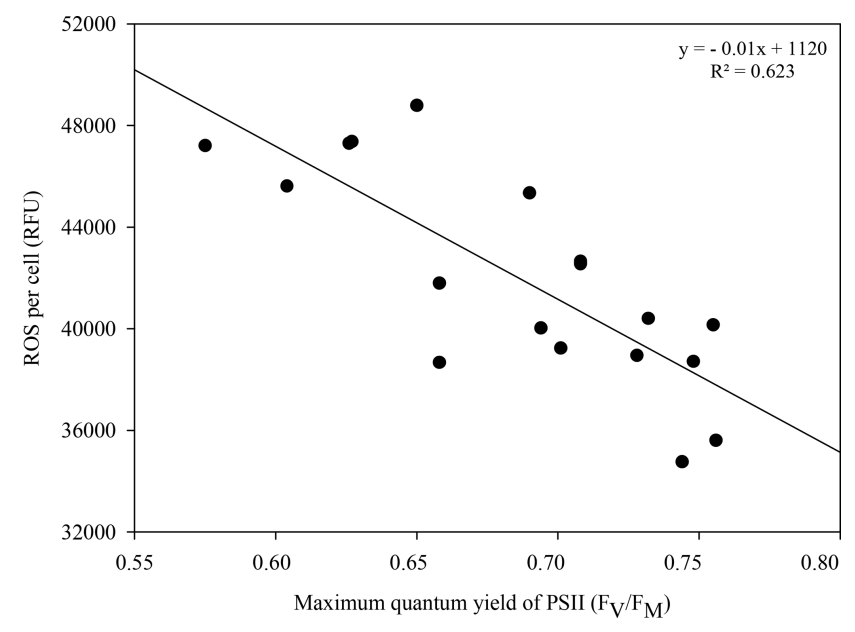

Figure 3. Correlation between the photosynthetic efficiency and reactive oxygen species (ROS) in Alexandrium minutum under the $32{ }^{\circ} \mathrm{C}$ thermal stress treatment; $n=18$.

$32^{\circ} \mathrm{C}$ compared to the $20^{\circ} \mathrm{C}$ control at all time points from $6 \mathrm{~h}$ after the start of the experiment ( $p \leq 0.01$; rmANOVA, Table 1, Fig. 2b). However, on days 5 and 6 , the $F_{\mathrm{V}} / F_{\mathrm{M}}$ of cultures kept at $32{ }^{\circ} \mathrm{C}$ recovered to values $(0.72 \pm 0.008)$ close to those of the control (0.75 \pm 0.004$)$ (Fig. $2 b)$, although it remained significantly lower than at $20^{\circ} \mathrm{C}(p<0.01$ and $p<0.001$ on days 5 and 6 respectively).

\subsection{Reactive oxygen species (ROS)}

Significantly lower concentrations of ROS were measured at $24^{\circ} \mathrm{C}$ than at $20^{\circ} \mathrm{C}$ at $96 \mathrm{~h}(p=0.003)$ and $120 \mathrm{~h}(p=$ 0.03) (rmANOVA, Table 1, Fig. 2c). In contrast, significantly greater concentrations of ROS were measured at $32^{\circ} \mathrm{C}$ than at $20^{\circ} \mathrm{C} 24 \mathrm{~h}(p<0.001), 96 \mathrm{~h}(p=0.001)$ and $120 \mathrm{~h}$ $(p=0.01)$ after the start of the experiment (rmANOVA, Table 1 , Fig. 2d). In line with the recovery in measured $F_{\mathrm{V}} / F_{\mathrm{M}}$, ROS concentrations in cultures kept at $32{ }^{\circ} \mathrm{C}$ started to decline to values closer to those of the control on days 5 and 6 of the experiment (Fig. 2d). A significant negative correlation between $F_{\mathrm{V}} / F_{\mathrm{M}}$ levels and ROS concentrations was observed under the $32^{\circ} \mathrm{C}$ temperature treatment $\left(R^{2}=0.623\right.$; $p=0.02, n=18$; Fig. 3).

\subsection{Biogenic sulfur dynamics}

Biogenic concentrations of DMSP, DMS and DMSO ranged from $424 \pm 35$ to $1629 \pm 170 \mathrm{fmol}_{\text {cell }}{ }^{-1}$, from $13 \pm 1.02$ to $87 \pm 5 \mathrm{fmol} \mathrm{cell}^{-1}$ and from $9 \pm 1.41$ to $94 \pm 24 \mathrm{fmolcell}^{-1}$, respectively, over both experiments (Fig. 4). Concentrations of all three sulfur compounds slowly decreased over time in all A. minutum cultures regardless of the temperature treatment. No significant difference in DMSP concentration was recorded between 20 and $24^{\circ} \mathrm{C}$ throughout the experiment ( $p>0.05$; rmANOVA, Table 1, Fig. $4 \mathrm{a})$, whereas signifi- cantly less DMSP was measured in cells at $32^{\circ} \mathrm{C}$ than in the $20^{\circ} \mathrm{C}$ control at $96 \mathrm{~h}(p=0.02 ;$ rmANOVA, Table 1 , Fig. 4b).

Significantly lower DMS concentrations were measured at $24^{\circ} \mathrm{C}$ compared to $20^{\circ} \mathrm{C}$ at $24 \mathrm{~h}(p<0.001)$ and $120 \mathrm{~h}$ $(p=0.002)$ (rmANOVA, Table 1, Fig. 4c). In contrast, DMS was significantly higher at $32^{\circ} \mathrm{C}$ than $20^{\circ} \mathrm{C} 6 \mathrm{~h}$ after the start of the experiment ( $p=0.008$; rmANOVA, Table 1, Fig. $4 \mathrm{~d})$. A similar pattern was observed for DMSO, which, relative to the controls, was significantly lower at $24^{\circ} \mathrm{C} 24 \mathrm{~h}$ after the start of the experiment $(p=0.001$; rmANOVA, Table 1 , Fig. 4e) and significantly greater at $32^{\circ} \mathrm{C}$ after 6 and $24 \mathrm{~h}$ $(p<0.05$, Fig. 4f).

\subsection{Bacterial abundance and composition}

Bacterial cell abundance exponentially increased over time at both 20 and $24^{\circ} \mathrm{C}$ (Fig. 5a). Bacterial abundance was significantly greater at $24^{\circ} \mathrm{C}$ than at $20^{\circ} \mathrm{C} 120 \mathrm{~h}$ after the start of the experiment $(p=0.05$; rmANOVA, Table 1 , Fig. 5a). However, no significant difference ( $p>0.05, t$ test) in bacterial growth rate was observed between $20^{\circ} \mathrm{C}(4.15 \pm$ $\left.0.05 \mathrm{~d}^{-1}\right)$ and $24^{\circ} \mathrm{C}\left(4.18 \pm 0.01 \mathrm{~d}^{-1}\right)$. In contrast, bacterial growth rate was significantly lower at $32^{\circ} \mathrm{C}$ than in the $20^{\circ} \mathrm{C}$ control $\left(4.05 \pm 0.01 \mathrm{~d}^{-1}\right.$ versus $4.23 \pm 0.02 \mathrm{~d}^{-1}$; $p<0.001, t$ test) (Fig. 5b), resulting in significantly lower bacterial cell densities at $24 \mathrm{~h}(p=0.002), 96 \mathrm{~h}(p=0.002)$ and $120 \mathrm{~h}(p<0.001)$ relative to the control (rmANOVA, Table 1, Fig. $5 b$ ).

The composition of the initial $\left(T_{0}\right)$ A. minutum microbiome was consistent across all samples, but then diverged significantly with time and between temperature treatments (Fig. 6a-b; Bray-Curtis similarity measurement, Shepard plot stress $=0.0587$ ). A significant temporal shift in bacterial composition occurred at both 20 and $32^{\circ} \mathrm{C}$, with dissimilarities in community composition between $T_{0}$ and $T_{120}$ of $27 \%$ and $42 \%$ occurring respectively (SIMPER analysis). Notably, bacterial communities at $32^{\circ} \mathrm{C}$ differed significantly (two-way PERMANOVA; $p<0.05$ ) to $20^{\circ} \mathrm{C}$ at $T_{120}$, with $32 \%$ dissimilarity in community composition. These differences were primarily driven by increased relative abundance of bacterial operational taxonomic units (OTUs) within the Oceanicaulis (17\%), Phycisphaeraceae SMIA02 (8.8\%) and Balneola (4.9\%) along with a decline in the relative abundance of OTUs matching Maribacter (24\%), Marinoscillum (4.7\%) and Seohaeicola (2.7\%) (Rhodobacteraceae family) in the $32{ }^{\circ} \mathrm{C}$ treatment (White test, Fig. 6c), with all taxa cumulatively contributing to $63 \%$ of the OTU differences between temperature treatments at $T_{120}$ (SIMPER analysis). In the $32{ }^{\circ} \mathrm{C}$ treatment, differences in microbiome composition between $T_{0}$ and $T_{120}$ were aligned with the elevated levels of ROS, while in the control $\left(20^{\circ} \mathrm{C}\right)$ the community shift was principally aligned with differences in bacterial and algal cell abundance (Fig. 6a; MDS analysis). Similarly, the elevated concentration of ROS as well as the lower $F_{\mathrm{V}} / F_{\mathrm{M}}$, lower al- 


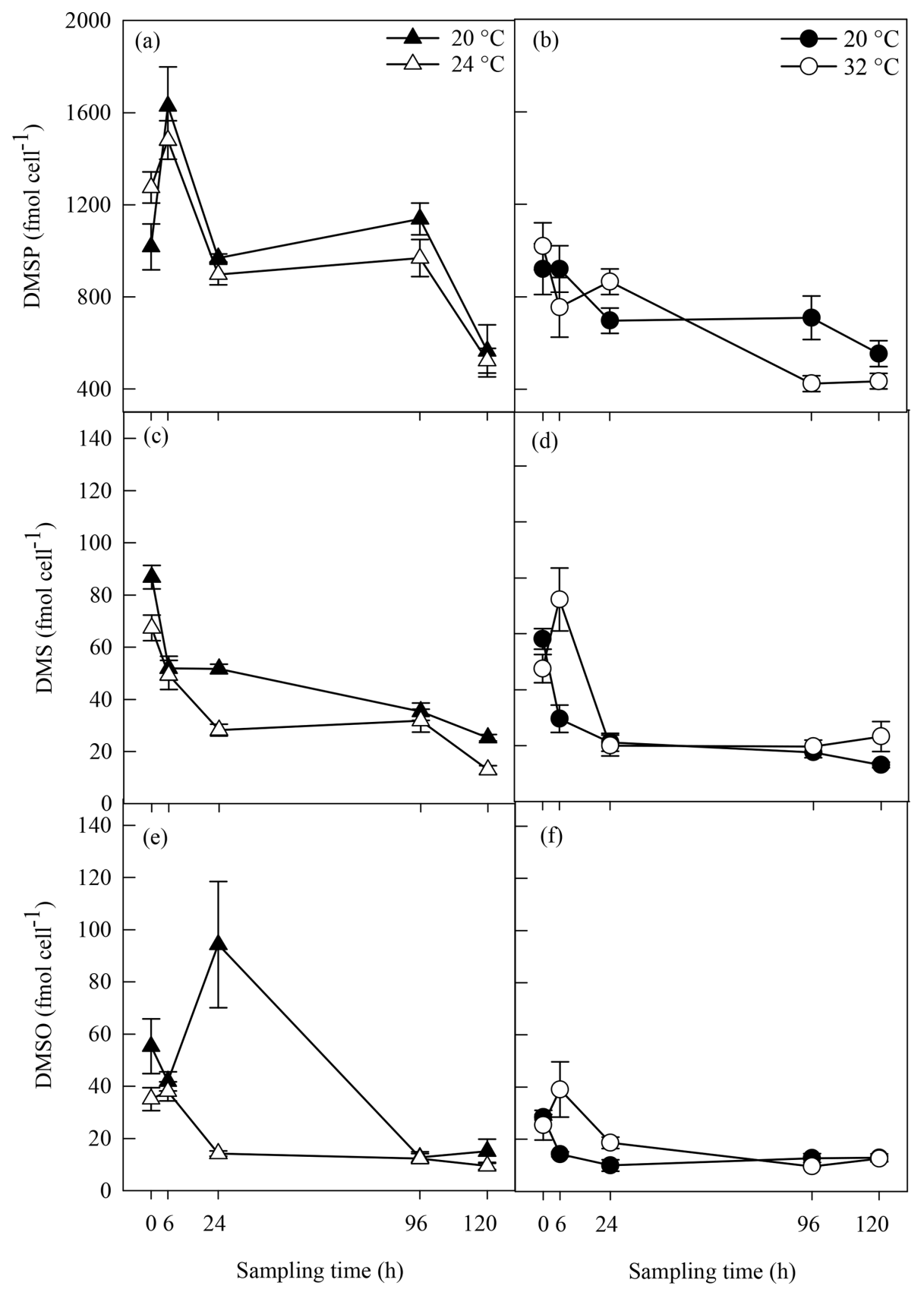

Figure 4. DMSP (a, b), DMS (c, d) and DMSO (e, f) concentrations in A. minutum cultures in experiment $1\left(20\right.$ and $\left.24^{\circ} \mathrm{C}\right)(\mathbf{a}, \mathbf{c}, \mathbf{e})$ and experiment $2\left(20\right.$ and $\left.32^{\circ} \mathrm{C}\right)(\mathbf{b}, \mathbf{d}, \mathbf{f})$; average $\pm \mathrm{SE}, n=4$. Variability in between the two $20^{\circ} \mathrm{C}$ controls is probably a consequence of experiments 1 and 2 being conducted at different times (April and June), whereby changes in the physiological state of the culture at each time led to different dimethylated sulfur profiles.

gal and bacterial cell abundance and lower DMSP, DMS and DMSO concentrations at $32^{\circ} \mathrm{C}$ were aligned with the differences in microbiome composition between the temperature treatments (Fig. 6b; MDS analysis).

\section{Discussion}

Climate change induced shifts within marine ecosystems are predicted to fundamentally alter the physiology of planktonic organisms and the biogeochemical transformations that they mediate (Finkel et al., 2009; Tortell et al., 2008; Hallegraeff, 2010). Rising seawater temperatures are one of the major impacts of climate change on marine ecosystems (Harley 


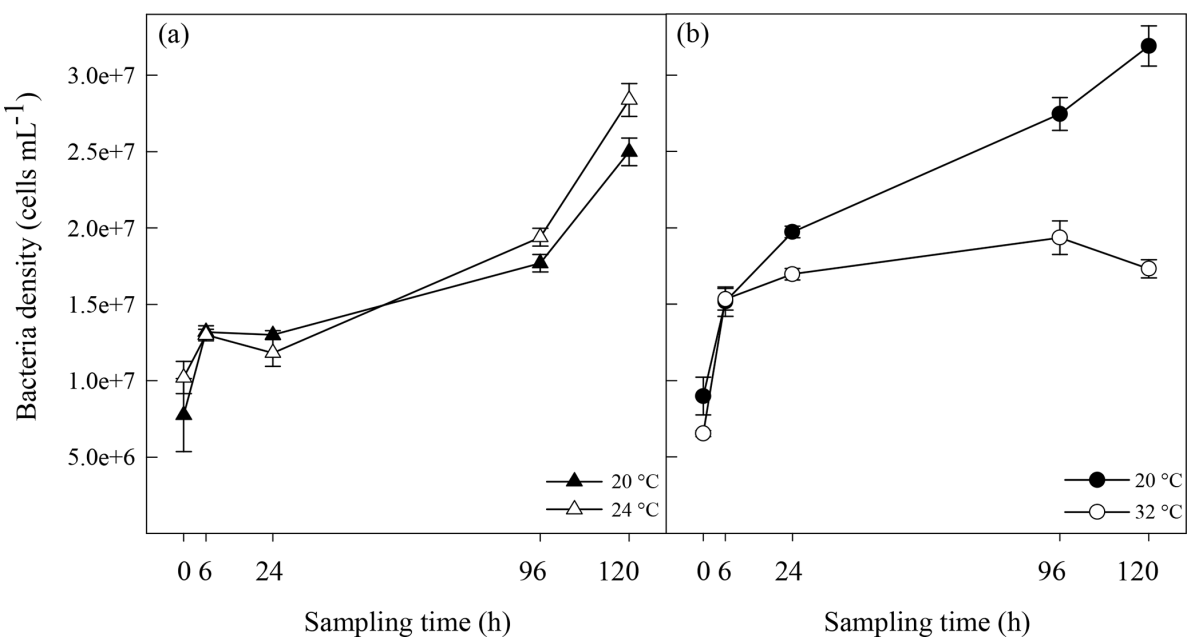

Figure 5. Bacterial cell abundance in A. minutum cultures in experiment 1 (20 and $\left.24^{\circ} \mathrm{C}\right)$ (a) and experiment $2\left(20\right.$ and $\left.32^{\circ} \mathrm{C}\right)(\mathbf{b})$; average $\pm \mathrm{SE}, n=4$.

(a)

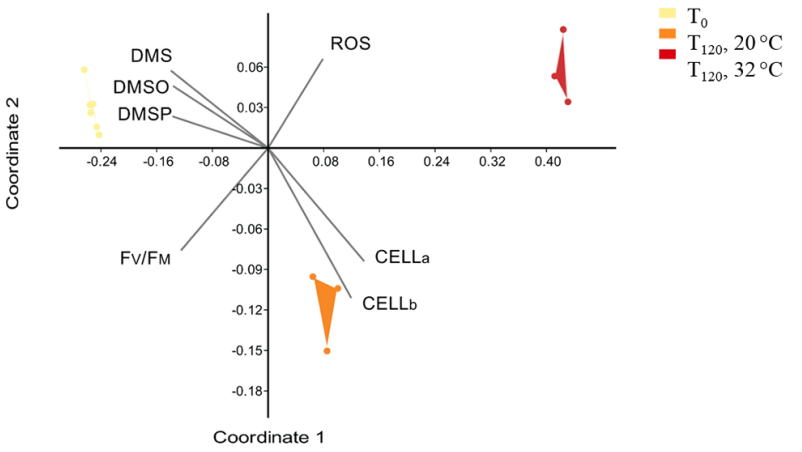

(b)

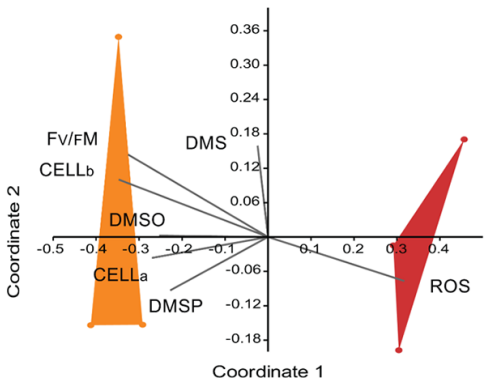

(c)

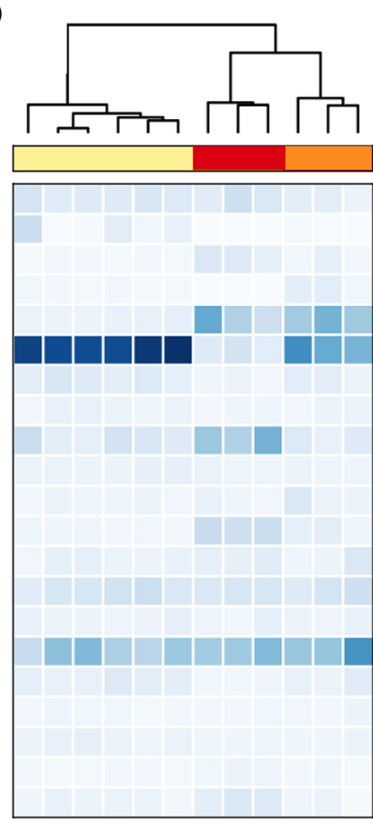

Sequences

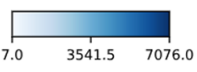

Alcanivoracaceae, Kangiella spp ${ }^{2}$

Alteromonadaceae spp

Owenweeksia crvomorphaceae ${ }^{1}$

Flammeovirgaceae, Marinoscillum spp 1,2,3

Flavobacteriaceae, Gilvibacter spp 1,2

Flavobacteriaceae, Maribacter spp 1,2,3

Flavobacteriaceae, Winogradskyella spp ${ }^{1}$

Hyphomicrobiaceae, Devosia spp

Hyphomonadaceae, Oceanicaulis spp ${ }^{1,3}$

Hyphomonadaceae spp ${ }^{2}$

Methylophllaceae, Methylotenera spp Phycisphaeraceae, SM1A02 spp 1,2,3

Phyllobacteraceae, Mesorhizobium spp

Rhodobacteraceae spp

Rhodobacteraceae, Marivita spp

Rhodobacteraceae, Roseovarius spp

Rhodobacteraceae, Seohaeicola spp 1,3

Rhodobacteraceae spp

Rhodobacteraceae spp 1,2

Sneathiellaceae, Sneathiella spp ${ }^{1}$

Balneola spp ${ }^{1,3}$

Figure 6. Multi-dimensional scaling (MDS) of the three phylogenetic groups defined by $16 \mathrm{~S}$ rRNA sequencing of the bacteria population associated with $A$. minutum cultures grown under control conditions $\left(20^{\circ} \mathrm{C}\right)$ and acute thermal stress $\left(32^{\circ} \mathrm{C}\right)$ at $T_{0}$ and $T_{120}($ a) and $\mathrm{MDS}$ excluding the $T_{0}$ control (b). Vectors represent the factors that most likely drove the shift in bacterial composition between groups. The taxonomic groups that significantly contributed to the difference in bacterial composition between $T_{0}$ and $T_{120}$ at $32^{\circ} \mathrm{C}\left({ }^{1}\right)$, between $T_{0}$ and $T_{120}$ at $20^{\circ} \mathrm{C}\left({ }^{2}\right)$ and between 32 and $20^{\circ} \mathrm{C}$ at $T_{120}\left({ }^{3}\right)$ appear in bold next to the heatmap (c), with scaling based on relative abundance.

et al., 2006), and they can be manifested both as long-term gradual increases (IPCC, 2007, 2013) or intense episodic marine heatwaves (Frölicher and Laufkötter, 2018; Hobday et al., 2016). Although less examined to date than chronic temperature increases, MHWs are predicted to become more frequent and severe (Oliver et al., 2018) and have been proposed as a mechanism for triggering toxic algal blooms (Ummenhofer and Meehl, 2017). Against this backdrop of changing environmental conditions, microbial production and cycling of dimethylated sulfur compounds could be particularly relevant because they simultaneously play a role in the stress response of marine phytoplankton (Berdalet et al., 2011; Deschaseaux et al., 2014a; Sunda et al., 2002; Wolfe et al., 2002; Stefels and van Leeuwe, 1998) and have been predicted to have biogeochemical feedback effects that are relevant for local climatic processes (Charlson et al., 1987). 
This study investigated the biogenic sulfur cycling dynamics of A. minutum, and its microbiome, in response to an extreme, short-term thermal stress event, akin to the marine heatwave events occurring with increasing frequency within coastal habitats (Oliver et al., 2018). Indeed, MHWs have been defined as an abrupt and ephemeral increase in temperature of at least 3 to $5{ }^{\circ} \mathrm{C}$ above climatological average that lasts for at least 3 to $5 \mathrm{~d}$ (Hobday et al., 2016). Large increases in temperature of about $8^{\circ} \mathrm{C}$ above the monthly climatological average led to red tides of exceptional density in San Francisco Bay (Cloern et al., 2005). While a $12^{\circ} \mathrm{C}$ increase in temperature constitutes an extreme scenario of MHWs even for coastal habitats, this experimental temperature was selected after preliminary investigations with the intention to induce thermal stress in this particularly robust strain of A. minutum in culture.

A. minutum has been targeted in this study as (1) an ecologically relevant phytoplankton responsible for some of the most harmful algal blooms (Anderson et al., 2012) and (2) as biochemically relevant for containing the highest DMSP concentrations ever reported in marine dinoflagellates (Caruana and Malin, 2014). However, it is to be noted that DMSP concentrations reported in this study were a degree of magnitude lower $\left(0.42 \pm 0.04\right.$ to $\left.1.63 \pm 1.70 \mathrm{pmol} \mathrm{cell}^{-1}\right)$ than that previously reported for $A$. minutum (14.2 pmol cell $^{-1}$; Caruana and Malin, 2014; Jean et al., 2005). This is potentially because this culture of A. minutum had been isolated from freeliving A. minutum for a long time (since 1988) or because culturing conditions failed to mimic the exact same biochemical conditions in which this strain of A. minutum usually grow. This biochemical difference could potentially reflect that this strain of A. minutum in culture was more robust than free-living dinoflagellates of the same species, thereby potentially justifying the need of a $12{ }^{\circ} \mathrm{C}$ increase in temperature to induce thermal stress.

\subsection{Effects of thermal stress on A. minutum growth, physiology and ROS production}

A mild increase in temperature $\left(4^{\circ} \mathrm{C}\right)$ resulted in faster algal growth and lower oxidative stress, indicating that $24^{\circ} \mathrm{C}$ was close to a temperature optimum for this strain of Alexandrium. This is perhaps not surprising considering that Alexandrium species are capable of growing under a wide range of temperatures from 12 to $25^{\circ} \mathrm{C}$ (Laabir et al., 2011). In contrast, an extreme increase in temperature $\left(12^{\circ} \mathrm{C}\right)$ resulted in a rapid and clear cascade of physiological responses, indicative of an acute thermal stress response in A. minutum. Overall, A. minutum cells exposed to $32^{\circ} \mathrm{C}$ immediately exhibited slower growth relative to the $20^{\circ} \mathrm{C}$ control, suggesting that a $12^{\circ} \mathrm{C}$ increase in temperature rapidly led to either an increase in cell death rate or a decrease in cell division (Rajadurai et al., 2005; Veldhuis et al., 2001). The slower growth rate at $32^{\circ} \mathrm{C}$ was coupled with a drop in photosynthetic efficiency and an increase in ROS concen- trations, which are both common stress responses to thermal stress in marine algae (Lesser, 2006; Falk et al., 1996; Robison and Warner, 2006; Iglesias-Prieto et al., 1992). In fact, these two physiological responses are often interconnected as increased ROS production generally occurs in both the chloroplast and mitochondria of marine algae exposed to thermal stress, causing lipid peroxidation and ultimately leading to a loss in thylakoid membrane integrity (Falk et al., 1996) and a decrease in the quantum yield of PSII (Lesser, 2006). This was reflected in the negative correlation observed between the maximum quantum yield of PSII and ROS concentrations.

Although photosynthetic efficiency remained impaired and ROS concentrations remained high under $32^{\circ} \mathrm{C}$ until the end of the experiment, both biomarkers of stress started to return to values closer to those of the $20^{\circ} \mathrm{C}$ control by days 5 and 6 of the experiment. This was most likely at the expense of a decline in algal abundance since slow growth often coincides with concurrent cellular repair and photosystem activity recovery (Robison and Warner, 2006). The differential physiological response between 24 and $32^{\circ} \mathrm{C}$ indicates that although cultures of this strain of $A$. minutum appear to be highly resistant to temperature changes, an abrupt increase in temperature of $12^{\circ} \mathrm{C}$ simulating an extreme case of marine heatwave led to a clear stress response. The physiological pattern at $32{ }^{\circ} \mathrm{C}$ also suggested an acclimation period necessary for such an abrupt shift in temperature, especially since recovery (in $F_{\mathrm{V}} / F_{\mathrm{M}}$ and ROS levels) was observed towards the end of the experiment.

\subsection{Biogenic sulfur cycling as a response to thermal stress in A. minutum}

Biogenic organic compounds are key compounds in the stress response of phytoplankton, with evidence they can be used in response to changes in temperature (Van Rijssel and Gieskes, 2002; Stefels, 2000). An upregulation of the biogenic sulfur yield was expected as a stress response to increased temperature in A. minutum, through either an increase in cellular DMSP concentrations, or an increase in DMS via the cleavage of DMSP (McLenon and DiTullio, 2012; Berdalet et al., 2011; Wolfe et al., 2002; Sunda et al., 2002). No significant change in DMSP concentrations was observed between the control and $24^{\circ} \mathrm{C}$ treatment, where, as described above, physiological responses converged to indicate that $24{ }^{\circ} \mathrm{C}$ was in fact a more optimal growth temperature for this organism. This temperature optimum was generally associated with lower DMS and DMSO concentrations than in the $20^{\circ} \mathrm{C}$ control, although this was only evident $24 \mathrm{~h}$ after the start of the experiment. Since algal stress responses often result in increased cellular sulfur concentrations in dinoflagellates (McLenon and DiTullio, 2012; Berdalet et al., 2011), it is perhaps not surprising that DMS and DMSO concentrations were lower under what appear to have been more optimal growth temperature conditions. 
In contrast to the lower DMS and DMSO concentrations observed at $24^{\circ} \mathrm{C}$ compared to the $20^{\circ} \mathrm{C}$ control, exposure to $32^{\circ} \mathrm{C}$ resulted in spikes in DMS and DMSO $6 \mathrm{~h}$ after the start of the experiment, which accompanied decreased algal growth and an impaired photosystem II. Although sporadic, the increases in DMS and DMSO observed in the $32^{\circ} \mathrm{C}$ treatment may have resulted from enhanced intracellular DMSP cleavage by phytoplankton (Del Valle et al., 2011) or enhanced DMSP exudation from phytoplankton cells during cell lysis (Simó, 2001), resulting in an increasing pool of dissolved DMSP made readily available to both bacteria and phytoplankton DMSP lyases (Riedel et al., 2015; Alcolombri et al., 2015; Todd et al., 2009, 2007). However, it is notable that lower DMSP concentrations in the $32{ }^{\circ} \mathrm{C}$ treatment than in the control only occurred on day 4 , whereas the spikes in DMS and DMSO were evident at the outset of the experiment $(6 \mathrm{~h})$. Since this decrease in DMSP at $96 \mathrm{~h}$ was not coupled with an increase in DMS, this could alternatively be indicative of a decrease in methionine synthase activity (McLenon and DiTullio, 2012) or assimilation of DMSP sulfur by bacterioplankton for de novo protein synthesis (Kiene et al., 2000), with this demethylation pathway often accounting for more than $80 \%$ of DMSP turnover in marine surface waters. The spike in DMSO measured $6 \mathrm{~h}$ after the increase in temperature to $32{ }^{\circ} \mathrm{C}$ most likely indicated rapid DMS oxidation by ROS under thermal stress (Sunda et al., 2002; Niki et al., 2000). At that time however, we found no evidence for ROS build-up in A. minutum cultures, possibly because ROS concentrations were kept in check by sufficient DMS synthesis and active DMS-mediated ROS scavenging (Lesser, 2006; Sunda et al., 2002). In contrast, $24 \mathrm{~h}$ after the start of the experiment, increased ROS coincided with an abrupt decline in DMS and DMSO, perhaps suggestive of serial oxidation via active ROS scavenging of both DMS to DMSO and DMSO to methane sulfinic acid (MSNA) (Sunda et al., 2002), although it is always difficult to confidently link DMS(O) and ROS dynamics unless using tracing techniques. It is also to be noted that measuring standing stocks may constitute a limitation to the capturing of subtle changes in DMS, DMSP and DMSO over time.

The only previous study that has examined sulfur responses to stress exposure in A. minutum examined the effect of physical turbulence by shaking $A$. minutum cultures for up to $4 \mathrm{~d}$ (Berdalet et al., 2011). While the authors of that study also observed slower cell growth as a response to stress exposure, in contrast to our study, cellular DMSP concentrations increased by $20 \%$. Here, a drop in DMSP concentration was observed at $96 \mathrm{~h}$ between the control and temperature treatment. Therefore, even though DMSP concentrations were quantified with a similar approach as in Berdalet et al. (2011) (no filtration of the samples with the assumption that particulate DMSP concentrations overrule dissolved DMSP and DMS concentrations), it seems that heat stress and turbulence triggered a dissimilar sulfur response to stress in A. minutum.
Overall, a $12{ }^{\circ} \mathrm{C}$ increase in temperature led to lower photosynthetic efficiency, increased oxidative stress and slower cell growth in this robust strain of the red-tide mediating dinoflagellate $A$. minutum. This physiological stress response was coupled with a differential biogenic sulfur cycling as shown by spikes in DMS and DMSO as well as lower DMSP concentrations, most likely translating ROS scavenging and DMSP uptake by bacterioplankton respectively. Because the turnover of DMS, DMSP and DMSO in biological systems can occur very quickly (Simó et al., 2000), DMS and DMSO concentrations can change rapidly, which sometimes makes it difficult to clearly establish cause-effect relationships between physiological stress and the biogenic sulfur response.

\subsection{A shift in A. minutum-associated bacteria composition triggered by thermal stress}

In light of DMSP and related biogenic sulfur compounds constituting an important source of carbon and sulfur to phytoplankton-associated bacteria (Kiene et al., 2000), it follows that any shift in biogenic sulfur concentrations could influence the microbiome composition of A. minutum. However, it is undeniable that a shift in the microbial community could also be driven by a range of physiological and biochemical parameters that were not measured in this study. Nevertheless, the most pronounced temporal shift in the composition of the bacterial community associated with A. minutum occurred in the $32{ }^{\circ} \mathrm{C}$ treatment. This shift was primarily characterised by a statistically significant increase in the relative abundance of OTUs classified as members of the Oceanicaulis, Phycisphaeraceae and Balneola and a significant decrease in OTUs classified as members of the Maribacter, Marinoscillum and Seohaeicola.

To predict any potential roles of these key OTUs in biogenic sulfur cycling processes, we screened the genomes of members of these groups using BLAST for four genes commonly involved in DMSP catabolism: $d m d A$, GenBank ID CP000031.2 (Howard et al., 2006); $d d d P$, GenBank ID KP639186 (Todd et al., 2009); tmm, GenBank ID JN797862 (Chen et al., 2011) and $d s y B$, GenBank ID KT989543 (Curson et al., 2017). A BLAST query of the sequences in the NCBI nucleotide collection (nr/nt) database revealed that previously sequenced members of the genera Maribacter (taxid:252356, 357 sequences), Oceanicaulis (taxid:153232, 36 sequences), Marinoscillum (taxid:643701, 23 sequences), Seohaeicola (taxid:481178, 18 sequences) and Balneola (taxid:455358, 44 sequences) did not possess any homologs of these sulfur cycling genes. While no homologs were found in the genus $S M 1 A 02$, perhaps because very little genomic information is available for this genus, a close phylogenetic relative to SM1A02 (99\% query cover, $80 \%$ identical, $E$ value $=0.0)$, and also a member of the Phycisphaeraceae family (P. mikurensis 10266 ; GenBank accession numbers AP012338.1), possessed significant homologs to all four query genes involved in DMSP metabolism: $d m d A$ (92\% 
identical, $E$ value $<0.001), d d d P(87 \%$ identical, $E$ value $=$ $0.003)$, tmm (82\% identical, $E$ value $=0.002)$ and $d s y B$ (92\% identical, $E$ value $<0.001$ ). It is thus possible that the spike in DMS and DMSO concentrations in the early stage of the $32^{\circ} \mathrm{C}$ heat treatment was a consequence of (or contributed to) the preferential recruitment of Phycisphaeraceae SM1A02.

Some members of the Rhodobacteraceae family such as several members of the Roseobacter genus and Rhodobacter sphaeroides are known to possess homologs of either or both $d m d A$ and $d d d$ genes, which are responsible for DMSP demethylation and DMSP-to-DMS cleavage respectively (Howard et al., 2006; Curson et al., 2008). However, none of the available reference genomes for Seohaeicola, a member of the Rhodobacteracea, possessed any homologs of targeted biogenic sulfur cycling. Similarly, members of the Maribacter, which was the main contributor to the difference in microbiome structure between the control and thermal stress treatment, are known not to possess DMSP or DMS transformation pathways (Kessler et al., 2018). Hence, the decline of this taxa in the heat stress treatments, where an upshift in biogenic sulfur availability occurred, is perhaps not surprising. However, this change in microbial abundance could have also been triggered by a range of other parameters that were not measured in this study.

Ultimately, the rapid changes in DMS and DMSO concentrations were potentially caused by (or led to) a shift in microbiome composition towards the preferential growth of sulfur-consuming bacteria (e.g. Phycisphaeraceae SM1A02) at the expense of other types of bacteria (e.g. Seohaeicola). Alternatively, the observed shifts in microbiome structure may have occurred independently to the biogenic sulfur cycling processes and were instead related to either temperature itself or other metabolic shifts in the heat-stressed A. minitum. Notably, the temporal shift in bacterial composition under thermal stress was associated with increased cellular ROS at the end of the experiment, indicating a potential link to oxidative stress.

\section{Conclusion}

Abrupt and intense increases in seawater temperatures associated with MHWs are predicted to become more frequent and intense (Oliver et al., 2018) and have the potential to influence the structure of coastal microbial assemblages and the nature of the important biogeochemical processes that they mediate. Here, we hypothesised that a very acute increase in temperature, mimicking an extreme scenario of coastal MHWs, would trigger both a physiological and biochemical stress response in the DMSP-producing dinoflagellate $A$. minutum. This response was indeed observed following a $12^{\circ} \mathrm{C}$ increase in temperature, with evidence for impaired photosynthetic efficiency, oxidative stress, spikes in DMS and DMSO concentrations, a drop in DMSP concen- tration and a shift in the composition of the A. minutum microbiome. These patterns are indicative of a profound shift in the physiological state and biochemical function of this ecologically relevant dinoflagellate in the context of MHWs and suggest that extreme thermal stress has the potential to not only influence the composition and interactions of coastal microbial food webs, but reshape sulfur budgets in coastal waters.

Data availability. All sequenced data file are available on NCBI under the study accession number PRJNA486692 (https: //www.ncbi.nlm.nih.gov/search/all/?term=PRJNA486692, last access: 19 August 2018). All physiological data and biogenic sulfur concentrations are available at https://osf.io/x3u24/?view_ only $=3 \mathrm{~b} 7 \mathrm{ac} 6 \mathrm{a} 0 \mathrm{~b} 8 \mathrm{f} 4432 \mathrm{aa} 816 \mathrm{~d} 0520 \mathrm{~b} 4 \mathrm{~d} 76 \mathrm{ef}$ (last access: 30 October 2019).

Author contributions. ED designed the experiment with KP and JRS. ED conducted the experiments as well as sample analysis, interpreted the data, conducted the statistical analysis and led the writing the paper. JO'B assisted in conducting the experiments, sample analysis and data interpretation. NS helped with the statistical analysis and interpretation of the sequencing data. KP and JRS financed the experiment.

Competing interests. The authors declare that they have no conflict of interest.

Acknowledgements. The work was funded by Australian Research Council grants FT130100218 and DP140101045 awarded to Justin R. Seymour and Katherina Petrou. We thank Rendy Ruvindy and Shauna Murray for providing the Alexandrium cultures and soil extracts. Bonnie Laverock provided advice on the DNA extractions.

Financial support. This research has been supported by the Australian Research Council (grant no. FT130100218) and the Australian Research Council (grant no. DP140101045).

Review statement. This paper was edited by Katja Fennel and reviewed by three anonymous referees.

\section{References}

Alcolombri, U., Ben-Dor, S., Feldmesser, E., Levin, Y., Tawfik, D. S., and Vardi, A.: Identification of the algal dimethyl sulfidereleasing enzyme: A missing link in the marine sulfur cycle, Science, 348, 1466-1469, https://doi.org/10.1126/science.aab1586, 2015 . 
Anderson, D. M.: Physiology and bloom dynamics of toxic Alexandrium species, with emphasis on life cycle transitions, Nato Asi Series G Ecological Sciences, 41, 29-48, 1998.

Anderson, D. M., Alpermann, T. J., Cembella, A. D., Collos, Y., Masseret, E., and Montresor, M.: The globally distributed genus Alexandrium: multifaceted roles in marine ecosystems and impacts on human health, Harmful Algae, 14, 10-35, 2012.

Berdalet, E., Llaveria, G., and Simó, R.: Modulation of dimethylsulfoniopropionate (DMSP) concentration in an Alexandrium minutum (Dinophyceae) culture by small-scale turbulence: A link to toxin production?, Harmful Algae, 11, 88-95, https://doi.org/10.1016/j.hal.2011.08.003, 2011.

Brimblecombe, P. and Shooter, D.: Photooxidation of dimethylsulfide in aqueous-solution, Mar. Chem., 19, 343-353, 1986.

Caporaso, J. G., Kuczynski, J., Stombaugh, J., Bittinger, K., Bushman, F. D., Costello, E. K., Fierer, N., Peña, A. G., Goodrich, J. K., and Gordon, J. I.: QIIME allows analysis of high-throughput community sequencing data, Nat. Methods, 7, 335-336, 2010.

Caruana, A. M. N. and Malin, G.: The variability in DMSP content and DMSP lyase activity in marine dinoflagellates, Prog. Oceanogr., 120, 410-424, https://doi.org/10.1016/j.pocean.2013.10.014, 2014.

Charlson, R. J., Lovelock, J. E., Andreae, M. O., and Warren, S. G.: Oceanic phytoplankton, atmospheric sulfur, cloud albedo and climate, Nature, 326, 655-661, 1987.

Chen, Y., Patel, N. A., Crombie, A., Scrivens, J. H., and Murrell, J. C.: Bacterial flavin-containing monooxygenase is trimethylamine monooxygenase, P. Natl. Acad. Sci. USA, 108, 1779117796, 2011.

Cloern, J. E., Schraga, T. S., and Lopez, C. B.: Heat wave brings an unprecedented red tide to San Francisco Bay, Eos, Transactions American Geophysical Union, 86, 66-66, 2005.

Curson, A. R., Todd, J. D., Sullivan, M. J., and Johnston, A. W.: Catabolism of dimethylsulphoniopropionate: microorganisms, enzymes and genes, Nat. Rev. Microbiol., 9, 849-859, 2011.

Curson, A. R. J., Rogers, R., Todd, J. D., Brearley, C. A., and Johnston, A. W. B.: Molecular genetic analysis of a dimethylsulfoniopropionate lyase that liberates the climate-changing gas dimethylsulfide in several marine alpha-proteobacteria and Rhodobacter sphaeroides, Environ. Microbiol., 10, 1099-1099, https://doi.org/10.1111/j.1462-2920.2008.01592.x, 2008.

Curson, A. R. J., Liu, J., Martínez, A. B., Green, R. T., Chan, Y., Carrión, O., Williams, B. T., Zhang, S.-H., Yang, G.-P., and Page, P. C. B.: Dimethylsulfoniopropionate biosynthesis in marine bacteria and identification of the key gene in this process, Nat. Microbiol., 2, 17009, 1-9, 2017.

DeBose, J. L., Lema, S. C., and Nevitt, G. A.: Dimethylsulfoniopropionate as a foraging cue for reef fishes, Science, 319, 13561356, https://doi.org/10.1126/science.1151109, 2008.

Del Valle, D. A., Slezak, D., Smith, C. M., Rellinger, A. N., Kieber, D. J., Kiene, R. P.: Effect of acidification on preservation of DMSP in seawater and phytoplankton cultures: Evidence for rapid loss and cleavage of DMSP in samples containing Phaeocystis sp., Mar. Chem., 124, 57-67, 2011.

Deschaseaux, E. S. M., Jones, G. B., Deseo, M. A., Shepherd, K. M., Kiene, R. P., Swan, H. B., Harrison, P. L., and Eyre, B. D.: Effects of environmental factors on dimethylated sulphur compounds and their potential role in the antioxidant system of the coral holobiont, Limnol. Oceanogr., 59, 758-768, 2014a.
Deschaseaux, E. S. M., Kiene, R. P., Jones, G. B., Deseo, M. A., Swan, H. B., Oswald, L., and Eyre, B. D.: Dimethylsulphoxide (DMSO) in biological samples: A comparison of the $\mathrm{TiCl} 3$ and $\mathrm{NaBH} 4$ reduction methods using headspace analysis, Mar. Chem., 164, 9-15, https://doi.org/10.1016/j.marchem.2014.05.004, 2014b.

Edgar, R. C.: Search and clustering orders of magnitude faster than BLAST, Bioinformatics, 26, 2460-2461, 2010.

Falk, S., Maxwell, D. P., Laudenbach, D. E., and Huner, N. P.: Photosynthetic adjustment to temperature, in: Photosynthesis and the environment, Springer, 367-385, 1996.

Finkel, Z. V., Beardall, J., Flynn, K. J., Quigg, A., Rees, T. A. V., and Raven, J. A.: Phytoplankton in a changing world: cell size and elemental stoichiometry, J. Plankton Res., 32, 119-137, 2009.

Frölicher, T. L. and Laufkötter, C.: Emerging risks from marine heat waves, Nat. Commun., 9, 650, https://doi.org/10.1038/s41467018-03163-6, 2018.

Hallegraeff, G. M.: Ocean climate change, phytoplankton community responses, and harmful algal blooms: a formidable predictive challenge, J. Phycol., 46, 220-235, https://doi.org/10.1111/j.1529-8817.2010.00815.x, 2010.

Hammer, Ø., Harper, D., and Ryan, P.: PAST-palaeontological statistics, ver. 1.89, Paleontological Museum, University of Oslo, Noruega, available at: http://folk.uio.no/ohammer/past/ index.html (last access: August 2017), 2008.

Harley, C. D. G., Hughes, A. R., Hultgren, K. M., Miner, B. G., Sorte, C. J. B., Thornber, C. S., Rodriguez, L. F., Tomanek, L., and Williams, S. L.: The impacts of climate change in coastal marine systems, Ecol. Lett., 9, 228-241, https://doi.org/10.1111/j.1461-0248.2005.00871.x, 2006.

Hobday, A. J., Alexander, L. V., Perkins, S. E., Smale, D. A., Straub, S. C., Oliver, E. C., Benthuysen, J. A., Burrows, M. T., Donat, M. G., and Feng, M.: A hierarchical approach to defining marine heatwaves, Prog. Oceanogr., 141, 227-238, 2016.

Howard, E. C., Henriksen, J. R., Buchan, A., Reisch, C. R., Bürgmann, H., Welsh, R., Ye, W., González, J. M., Mace, K., and Joye, S. B.: Bacterial taxa that limit sulfur flux from the ocean, Science, 314, 649-652, 2006.

Hughes, T. P., Kerry, J. T., Álvarez-Noriega, M., Álvarez-Romero, J. G., Anderson, K. D., Baird, A. H., Babcock, R. C., Beger, M., Bellwood, D. R., and Berkelmans, R.: Global warming and recurrent mass bleaching of corals, Nature, 543, 373-377, 2017.

Iglesias-Prieto, R., Matta, J. L., Robins, W. A., and Trench, R. K.: Photosynthetic response to elevated temperature in the symbiotic dinoflagellate Symbiodinium microadriaticum in culture, P. Natl. Acad. Sci. USA, 89, 10302-10305, 1992.

IPCC: Climate change 2007: The physical science basis. Contribution of working group II to the fourth assessment report of the Intergovernmental Panel on Climate Change, Cambridge, United Kingdom and New York, 2007.

IPCC: The physical science basis: working group I contribution to the fifth assessment report of the intergovernmental panel of climate change, Cambridge, United Kingdom and New York, 2013.

Jean, N., Boge, G., Jamet, J. L., Richard, S., and Jamet, D.: Annual contribution of different plankton size classes to particulate dimethylsulfoniopropionate in a marine perturbed ecosystem, J. Mar. Syst., 53, 235-247, 2005. 
Joint, I. and Smale, D. A.: Marine heatwaves and optimal temperatures for microbial assemblage activity, FEMS Microbiol. Ecol., 93, 1-9, 2017.

Kessler, R. W., Weiss, A., Kuegler, S., Hermes, C., and Wichard, T.: Macroalgal-bacterial interactions: Role of dimethylsulfoniopropionate in microbial gardening by Ulva (Chlorophyta), Mol. Ecol., 27, 1808-1819, 2018.

Kiene, R. P. and Gerard, G.: Determination of trace levels of dimethylsulfoxide (DMSO) in seawater and rainwater, Mar. Chem., 47, 1-12, 1994.

Kiene, R. P. and Slezak, D.: Low dissolved DMSP concentrations in seawater revealed by small-volume gravity filtration and dialysis sampling, Limnol. Oceanogr. Meth., 4, 80-95, 2006.

Kiene, R. P., Linn, L. J., and Bruton, J. A.: New and important roles for DMSP in marine microbial communities, J. Sea. Res., 43, 209-224, 2000.

Knight, K.: Hatchling loggerhead turtles pick up DMS, J. Exp. Biol., 215, 3535-3538, 2012.

Kuczynski, J., Stombaugh, J., Walters, W. A., González, A., Caporaso, J. G., and Knight, R.: Using QIIME to analyze 16S rRNA gene sequences from microbial communities, Current protocols in microbiology, 1E, 5.1-1E, 5.20, 2012.

Laabir, M., Jauzein, C., Genovesi, B., Masseret, E., Grzebyk, D., Cecchi, P., Vaquer, A., Perrin, Y., and Collos, Y.: Influence of temperature, salinity and irradiance on the growth and cell yield of the harmful red tide dinoflagellate Alexandrium catenella colonizing Mediterranean waters, J. Plankton Res., 33, 1550-1563, 2011.

Lane, D. J.: 16S/23S rRNA sequencing, in: Nucleic acid techniques in bacterial systematics, edited by: Stackebrandt, E. and Goodfellow, M., John Wiley and Sons, New York, NY, 115-175, 1991.

Lesser, M. P.: Oxidative stress in marine environments: Biochemistry and physiological ecology, Annu. Rev. Physiol., 68, 253278, https://doi.org/10.1146/annurev.physiol.68.040104.110001, 2006.

Marie, D., Partensky, F., Jacquet, S., and Vaulot, D.: Enumeration and cell cycle analysis of natural populations of marine picoplankton by flow cytometry using the nucleic acid stain SYBR Green I, Appl. Environ. Microbiol., 63, 186-193, 1997.

McLenon, A. L. and DiTullio, G. R.: Effects of increased temperature on dimethylsulfoniopropionate (DMSP) concentration and methionine synthase activity in Symbiodinium microadriaticum, Biogeochem., 110, 17-29, https://doi.org/10.1007/s10533-0129733-0, 2012.

Nevitt, G. A., Veit, R. R., and Kareiva, P.: Dimethyl sulfide as a foraging cue for Antarctic procellariform seabirds, Nature, 376, 680-682, https://doi.org/10.1038/376680ao, 1995.

Niki, T., Kunugi, M., and Otsuki, A.: DMSP-lyase activity in five marine phytoplankton species: its potential importance in DMS production, Mar. Biol., 136, 759-764, 2000.

Oliver, E. C. J., Donat, M. G., Burrows, M. T., Moore, P. J., Smale, D. A., Alexander, L. V., Benthuysen, J. A., Feng, M., Sen Gupta, A., Hobday, A. J., Holbrook, N. J., Perkins-Kirkpatrick, S. E., Scannell, H. A., Straub, S. C., and Wernberg, T.: Longer and more frequent marine heatwaves over the past century, Nat. Commun., 9, 1324, https://doi.org/10.1038/s41467-018-037329, 2018.

Quast, C., Pruesse, E., Yilmaz, P., Gerken, J., Schweer, T., Yarza, P., Peplies, J., and Glöckner, F. O.: The SILVA ribosomal RNA gene database project: improved data processing and web-based tools, Nucleic Acids Res., 41, D590-D596, 2012.

Rajadurai, M., Poornima, E. H., Narasimhan, S. V., Rao, V. N. R., and Venugopalan, V. P.: Phytoplankton growth under temperature stress: Laboratory studies using two diatoms from a tropical coastal power station site, J. Therm. Biol., 30, 299-305, https://doi.org/10.1016/j.jtherbio.2005.01.003, 2005.

Rastogi, R. P., Singh, S. P., Häder, D.-P., and Sinha, R. P.: Detection of reactive oxygen species (ROS) by the oxidant-sensing probe $2^{\prime}, 7^{\prime}$-dichlorodihydrofluorescein diacetate in the cyanobacterium Anabaena variabilis PCC 7937, Biochem. Bioph. Res. Co., 397, 603-607, 2010.

Riedel, T., Spring, S., Fiebig, A., Scheuner, C., Petersen, J., Göker, M., and Klenk, H. P.: Genome sequence of the roseovarius mucosus type strain (Dsm 17069T), a bacteriochlorophyll $a$ containing representative of the marine roseobacter group isolated from the dinoflagellate alexandrium ostenfeldii, Stand. Genomic Sci., 10, 1-12, https://doi.org/10.1186/1944-3277-10-17, 2015.

Robison, J. D. and Warner, M. E.: Differential impacts of photoacclimation and thermal stress on the photobiology of four different phylotypes of Symbiodinium (pyrrhophyta) 1, J. Phycol., 42, 568-579, 2006.

Seymour J. R., Sim, R., Ahmed, T., and Stocker, R.: Chemoattraction to dimethylsulfoniopropionate throughout the marine microbial food web, Science, 329, 342-345, 2010.

Simó, R., Pedrós-Alió, C., Malin, G., and Grimalt, J. O.: Biological turnover of DMS, DMSP and DMSO in contrasting open-sea waters, Mar. Ecol. Prog. Ser., 230, 1-11, 2000.

Simó, R.: Production of atmospheric sulfur by oceanic plankton: biogeochemical, ecological and evolutionary links, Trends Ecol. Evol., 16, 287-294, 2001.

Stefels, J.: Physiological aspects of the production and conversion of DMSP in marine algae and higher plants, J. Sea. Res., 43, 183-197, 2000.

Stefels, J. and van Leeuwe, M. A.: Effects of iron and light stress on the biochemical composition of Antarctic Phaeocystis sp. (Prymnesiophyceae). I. Intracellular DMSP concentrations, J. Phycol., 34, 486-495, https://doi.org/10.1046/j.15298817.1998.340486.x, 1998.

Sunda, W., Kieber, D. J., Kiene, R. P., and Huntsman, S.: An antioxidant function for DMSP and DMS in marine algae, Nature, 418, 317-320, 2002.

Todd, J. D., Rogers, R., Li, Y. G., Wexler, M., Bond, P. L., Sun, L., Curson, A. R. J., Malin, G., Steinke, M., and Johnston, A. W. B.: Structural and regulatory genes required to make the gas dimethyl sulfide in bacteria, Science, 315, 666-669, https://doi.org/10.1126/science.1135370, 2007.

Todd, J. D., Curson, A. R. J., Dupont, C. L., Nicholson, P., and Johnston, A. W. B.: The dddP gene, encoding a novel enzyme that converts dimethylsulfoniopropionate into dimethyl sulfide, is widespread in ocean metagenomes and marine bacteria and also occurs in some Ascomycete fungi, Environ. Microbiol., 11, 1376-1385, https://doi.org/10.1111/j.14622920.2009.01864.x, 2009.

Tortell, P. D., Payne, C. D., Li, Y., Trimborn, S., Rost, B., Smith, W. O., Riesselman, C., Dunbar, R. B., Sedwick, P., and DiTullio, G. R.: $\mathrm{CO}_{2}$ sensitivity of Southern Ocean phytoplankton, Geophys. 
Res. Lett., 35, L04605, https://doi.org/10.1029/2007GL032583, 2008.

Turner, S., Pryer, K. M., Miao, V. P., and Palmer, J. D.: Investigating deep phylogenetic relationships among cyanobacteria and plastids by small subunit rRNA sequence analysis, J. Eukaryot. Microbiol., 46, 327-338, 1999.

Ummenhofer, C. C. and Meehl, G. A.: Extreme weather and climate events with ecological relevance: a review, Phil. Trans. R. Soc. B, 372, 20160135, https://doi.org/10.1098/rstb.2016.0135, 2017.

Van Alstyne, K. L., Wolfe, G. V., Freidenburg, T. L., Neill, A., and Hicken, C.: Activated defense systems in marine macroalgae: evidence for an ecological role for DMSP cleavage, Mar. Ecol. Prog. Ser., 213, 53-65, 2001.

Van Rijssel, M. and Gieskes, W. W. C.: Temperature, light, and the dimethylsulfoniopropionate (DMSP) content of Emiliania huxleyi (Prymnesiophyceae), J. Sea. Res., 48, 17-27, 2002.
Veldhuis, M. J., Kraay, G. W., and Timmermans, K. R.: Cell death in phytoplankton: correlation between changes in membrane permeability, photosynthetic activity, pigmentation and growth, Eur. J. Phycology, 36, 167-177, 2001.

Wolfe, G. V., Strom, S. L., Holmes, J. L., Radzio, T., and Olson, M. B.: Dimethylsulfoniopropionate cleavage by marine phytoplankton in response to mechanical, chemical, or dark stress, J. Phycol., 38, 948-960, https://doi.org/10.1046/j.1529-8817.2002.t011-01100.x, 2002.

Yilmaz, P., Parfrey, L. W., Yarza, P., Gerken, J., Pruesse, E., Quast, C., Schweer, T., Peplies, J., Ludwig, W., and Glöckner, F. O.: The SILVA and "all-species living tree project (LTP)" taxonomic frameworks, Nucleic Acids Res., 42, D643-D648, 2013.

Zhou, C. X., Xu, J. L., Yan, X. J., Hou, Y. D., and Jiang, Y.: Analysis of dimethylsulfide and dimethylsulfoniopropionate in marine microalgae culture, Chin. J. Anal. Chem., 37, 1308-1312, 2009. 